Mastering

\title{
Pascal and Delphi Programming
}


Accounting

Advanced English Language

Advanced Pure Mathematics

Arabic

Banking

Basic Management

Biology

British Politics

Business Administration

Business Communication

Business Law

C Programming

$\mathrm{C}++$ Programming

Catering Theory

Chemistry

COBOL Programming

Communication

Databases

Economic and Social History

Economics

Electrical Engineering

Electronic and Electrical Calculations

Electronics

English as a Foreign Language

English Grammar

English Language

English Literature

French

French 2

German

German 2
Global Information Systems

Human Biology

Internet

Italian

Italian 2

Java

Manufacturing

Marketing

Mathematics

Mathematics for Electrical and

Electronic Engineering

Microsoft Office

Modern British History

Modern European History

Modern World History

Pascal and Delphi Programming

Philosophy

Photography

Physics

Psychology

Science

Shakespeare

Social Welfare

Sociology

Spanish

Spanish 2

Statistics

Study Skills

Visual Basic

World Religions

\section{Macmillan Master Series}

Series Standing Order ISBN 978-0-333-69343-8

(outside North America only)

You can receive future titles in this series as they are published by placing a standing order. Please contact your bookseller or, in case of difficulty, write to us at the address below with your name and address, the title of the series and the ISBN quoted above.

Customer Services Department, Macmillan Distribution Ltd

Houndmills, Basingstoke, Hampshire RG21 6XS, England 


\section{Mastering}

\section{Pascal and Delphi}

Programming

William Buchanan, BSc, CEng, $\mathrm{PhD}$

Senior Lecturer

Department of Electrical and Electronic Engineering

Napier University

Edinburgh

Series Editor

William Buchanan

MACMILLAN 
C William Buchanan 1998

All rights reserved. No reproduction, copy or transmission of this publication may be made without written permission.

No paragraph of this publication may be reproduced, copied or transmitted save with written permission or in accordance with the provision of the Copyright, Designs and Patents Act 1988, or under the terms of any licence permitting limited copying issued by the Copyright Licensing Agency, 90 Tottenham Court Road, London W1P 9HE.

Any person who does any unauthorised act in relation to this publication may be liable to criminal prosecution and civil claims for damages.

The author has asserted his right to be identified as the author of this work in accordance with the Copyright, Designs and Patents Act 1988.

Published 1998 by

MACMILLAN PRESS LTD

Houndmills, Basingstoke, Hampshire RG21 6XS

and London

Companies and representatives

throughout the world

ISBN 978-0-333-73007-2

ISBN 978-1-349-14770-0 (eBook)

DOI 10.1007/978-1-349-14770-0

A catalogue record for this book is available

from the British Library.

This book is printed on paper suitable for recycling and made from fully managed and sustained forest sources.

$\begin{array}{llllllllll}10 & 9 & 8 & 7 & 6 & 5 & 4 & 3 & 2 & 1\end{array}$

$\begin{array}{llllllllll}07 & 06 & 05 & 04 & 03 & 02 & 01 & 00 & 99 & 98\end{array}$ 


\section{Contents}

Preface

1 Introduction

1.1 Introduction

1.2 Hardware, software and firmware

1.3 Basic computer architecture

1.4 Compiling, linking and producing an executable program

1.5 Compilation

1.6 Introduction to Pascal

1.7 Exercises

2 Input/Output

2.1 Introduction

2.2 Pascal input/output

2.3 Examples

2.4 Exercises

3 If Statement

3.1 if...else statements $\quad 20$

3.2 Examples $\quad 21$

3.3 Exercises $\quad 26$

4 Case Statement 29

4.1 case statement 29

4.2 Examples $\quad 29$

4.3 Exercises $\quad 33$

5 For Loop $\quad 36$

5.1 Introduction $\quad 36$

5.2 for $\quad 36$

5.3 Examples $\quad 37$

5.4 Exercises 39

6 While/Repeat Loops 42

6.1 while $\quad 42$

6.2 Repeat...until $\quad 42$

6.3 Examples $\quad 43$

6.4 Exercises 46 
7 Functions $\quad \mathbf{5 0}$

7.1 Introduction $\quad 50$

7.2 Arguments and parameters $\quad 50$

7.3 Pascal functions 51

7.4 Local variables $\quad 54$

7.5 Examples $\quad 55$

7.6 Exercises $\quad 62$

8 Procedures $\quad 65$

8.1 Introduction $\quad 65$

8.2 Pascal parameter passing $\quad 65$

8.3 Examples 67

8.4 Exercises 71

9 Arrays $\quad 76$

9.1 Introduction 76

9.2 Pascal arrays $\quad 76$

9.3 Examples $\quad 79$

9.4 Multidimensional arrays $\quad 85$

9.5 Exercises $\quad 87$

10 Strings $\quad 92$

10.1 Introduction $\quad 92$

10.2 Pascal strings $\quad 92$

10.3 Examples $\quad 95$

10.4 Exercises 100

11 File I/O 103

11.1 Introduction 103

11.2 Pascal file I/O 105

11.3 Examples $\quad 106$

11.4 Exercises 110

12 Records 113

12.1 Introduction 113

12.2 Records in Pascal 113

12.3 Array of structures $\quad 116$

12.4 Exercises 119

13 Graphics $\quad 123$

13.1 Introduction 123

13.2 Basic graphics routines $\quad 128$

13.3 Exercises 138 
14.1 Introduction $\quad 140$

14.2 BIOS and the operating system $\quad 140$

14.3 Interrupt vectors 141

14.4 Processor interrupts $\quad 142$

14.5 Generating software interrupts 142

14.6 Exercises 155

15 Interfacing $\quad 158$

15.1 Introduction 158

15.2 Interfacing with memory $\quad 159$

15.3 Memory mapped I/O 159

15.4 Isolated $\mathrm{V} / \mathrm{O} \quad 160$

16 RS-232 $\quad 165$

16.1 Introduction $\quad 165$

16.2 Electrical characteristics $\quad 165$

16.3 Frame format $\quad 168$

16.4 Communications between two nodes 169

16.5 Programming RS-232 173

$\begin{array}{ll}16.6 \text { RS-232 programs } & 178\end{array}$

16.7 Exercises 181

17 Parallel Port 184

17.1 Introduction $\quad 184$

17.2 PC connections $\quad 185$

$\begin{array}{ll}\text { 17.3 Data handshaking } & 185\end{array}$

$17.4 \mathrm{~J} / \mathrm{O}$ addressing $\quad 188$

17.5 Exercises 193

$\begin{array}{lll}18 & \text { Hardware Interrupts } & 197\end{array}$

18.1 Introduction 197

18.2 Hardware interrupts $\quad 198$

18.3 Interrupt vectors 199

18.4 Programmable interrupt controller (PIC) 202

18.5 Interrupt-driven RS-232 204

18.6 Exercices 211

19 Date and Time 213

19.1 Introduction 213

19.2 Time $\quad 214$

19.3 Date $\quad 214$

19.4 DateTime record 215 
19.5 Packing Time $\quad 215$

19.6 File Time $\quad 215$

19.7 Examples $\quad 216$

19.8 Counting timer ticks $\quad 218$

19.9 Exercises $\quad 219$

20 System Commands $\quad 220$

20.1 Introduction $\quad 220$

20.2 System calls $\quad 220$

20.3 Passing arguments 226

20.4 Exercises 228

21 Introduction to Delphi 230

21.1 Introduction 230

21.2 Event-driven programming $\quad 230$

21.3 Delphi files 231

21.4 Other terms $\quad 232$

21.5 Main screen 233

21.6 Object Inspector $\quad 236$

21.7 Exercises 240

22 Delphi Input/Output 243

22.1 Introduction 243

22.2 Running Pascal programs 244

22.3 Message and dialog boxes $\quad 246$

22.4 Input dialog 254

22.5 Exercises 256

23 Delphi Forms $\quad 258$

23.1 Introduction 258

23.2 Setting properties 258

23.3 Forms and code $\quad 259$

23.4 Temperature conversion program 266

23.5 Quadratic roots program 270

23.6 Resistance calculation with slider controls program 272

23.7 Exercises 279

24 Delphi Menus and Dialogs 281

24.1 Introduction 281

24.2 Menu editor 281

24.3 Open and close dialog boxes 286

24.4 Running an application program 289

24.5 Exercises 290 
25.1 Introduction 292

25.2 Program events 292

25.3 Exercises 301

26 Delphi Graphics $\quad 303$

26.1 Introduction 303

26.2 Loading graphics files $\quad 303$

26.3 Colours 305

26.4 Drawing $\quad 306$

26.5 Exercises $\quad 312$

A Turbo Pascal Reference $\quad 314$

$\begin{array}{lll}\text { B ASCII } & 325\end{array}$

C Bits, Bytes and Operators 329

C.1 Bits and bytes 329

C.2 Binary arithmetic $\quad 330$

C.3 Numbers and representations 331

C.4 Pascal operators 333

D Dephi Reference $\quad 338$

D.1 Standard units 338

D.2 Forms unit $\quad 339$

D.3 WinProcs unit 340

D.4 System unit $\quad 354$

D.5 Dialogs unit 356

E Miscellaneous $\quad 358$

E.1 Structure charts 358

E.2 Programs with errors 359

$\begin{array}{ll}\text { Index } & 366\end{array}$ 
Pascal is one of the most widely used PC-based programming languages. It is also one of the best programming languages to teach good software development techniques. This book provides an introduction to programming with Pascal and extends this to show how Borland Delphi, which uses Pascal, is used to develop Microsoft Windows programs.

After many years of teaching software development to undergraduates I have found that $\mathrm{C}$ and $\mathrm{C}++$ suffer from several pitfalls, especially in parameter passing, pointers and the lack of strong data type checking. These areas may provide flexibility for experienced programmers, but for novices they add to the complexity of the program.

I have also been involved with extensive consultancy work and book writing over the years and I have used $\mathrm{C}, \mathrm{C}++$ (Borland $\mathrm{C}++$ and Visual $\mathrm{C}++$ ), HTML/JavaScript, Java, Visual Basic, Turbo Pascal and Borland Delphi. From this, I can say, without doubt, that Delphi is the easiest and most powerful development system I have found. It provides a great deal of flexibility in that it doesn't try to write all the code for the programmer, and basically it provides a framework for the user to add code to.

The best way to learn a programming language is to write real applications. For this reason the book includes many real-life applications. Chapters 13 to 20 cover some practical applications, such as: software interrupts, hardware interrupts, graphics, date and time, system commands, RS-232 and parallel ports.

The book thus covers three main areas:

- Pascal programming (Chapters 1 to 12).

- Pascal applications (Chapters 13 to 20).

- Delphi programming (Chapters 21 to 26).

Further information and source code can be found on the WWW page:

http://www.eece.napier.ac.uk/ bill_b/pascal.html

Help from myself can be sought using the email address:

w.buchanan@napier.ac.uk

Dr. William Buchanan. 